EISSN: 2706-7955 ISSN: 2077-4605

DOI: $10.36632 /$ mejar/2021.10.1.14

Journal homepage: www.curresweb.com

Pages: 238-255

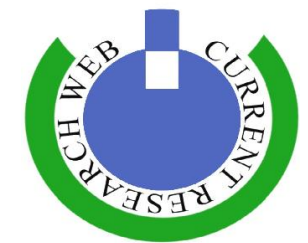

\title{
Effect of planting date and foliar application of some macro elements on storability and prolonging the marketing period of sweet potato
}

\author{
EL-Anany A. M. A. \\ Potato and Vegetatively Propagated Vegetables Dep., Hort. Res., Inst., A.R.C., Giza, 12619, Egypt
}

\author{
Received: 15 December 2020 Accepted: 28 February 2021 Published: 05 March 2021
}

\begin{abstract}
An agricultural field experiment was conducted during the two consecutive seasons of 2016 and 2017 in Kaha Vegetable Research Farm, Horticultural Research Institute, to study the effect of planting dates and spraying with some minerals on storage capacity and prolonging the marketing period for sweet potato (Ipomoea batatas, L.), cv. Menoufia 6. The experiment included 12 treatments, which are: Three planting dates as main treatments with four sub-treatments, i.e., foliar spraying with $2500 \mathrm{ppm}$ potassium, 2000ppm calcium and $1500 \mathrm{ppm}$ magnesium five times throughout the season. Results indicated that the first planting date (April) with potassium foliar spray gave the highest values of vegetative growth (plant length, number of branches, fresh and dry weight of canopy). The interaction between planting dates and nutrients foliar spray was positive on yield and its components (root length, number of roots, roots fresh weight, total yield/fed and marketable yield). First planting date with spraying of mineral nutrients recorded the highest values of both total and marketable yield of tuberous roots compared to the second and third planting dates, where the first planting date superiority followed by the second planting date and the third planting date in descending order, while the cash return was higher in the third planting date compared to the first and second planting dates due to the decrease in the supply of the crop during the harvest period. The results also indicate an increase in the chemical content in the tested plant samples (tuberous roots) in the three planting dates, and it seems that the accumulation of the chemical content inside the tuberous roots had a positive effect on the storage capacity of the tuberous roots for the three planting dates but this effect doubled with the decrease in temperature during the storage period on the third planting date, which recorded the lowest values in the percentage of loss in weight and in the percentage of decay, during the experimental seasons, and this may be due to the suitability of temperature and humidity during the months of storage and the interaction of this with the spraying with mineral elements that work on building and solids of the cell walls and resisting the changes resulting from the external environment. The economic study showed that, sweet potato on-farm storage in is a viable and potentially highly profitable business in Egypt. It was found that the longer the storage period (in case of $2^{\text {nd }}$ planting date), the higher the monetary value of the venture where, it increases with the increase of the storage period up to 120 days. Storing sweet potatoes for 8 weeks (Both June and August planting dates) would still represent a viable business which is not recommended at April plantings in which the stored yield do not sold off before 90 and 120 days (the highest monetary value under all nutrient treatments over the corresponding treatments at harvest time by storing April planting up to 120 days) in order to avoid the loss resulting from the sale after storage periods of 30 or 60 days.
\end{abstract}

Keywords: Sweet potato, foliar spraying, planting date, potassium, calcium, magnesium, marketable and storage.

\section{Introduction}

Sweet potato (Ipomoea batatas L.) is a dicotyledonous root vegetable crop that belongs to the family Convolvulaceae and is the seventh important food crop after wheat, rice, corn, potatoes, barley and cassava in the world (El-Seifi et al., 2014). In Egypt, the area cultivated with sweet potato in Egypt

Corresponding Author: EL-Anany A. M. A., Potato and Vegetatively Propagated Vegetables Dep., Hort. Res., Inst., A.R.C., Giza, 12619, Egypt. E-mail: 
2018/2019 season is about 613 feddans, with a total production of 3762 ton/fed (Egyptian Ministry of Agriculture and Land Reclamation, 2019), it is a popular crop and is cultivated for the purpose of human food, animals fodder and industrial purposes, i.e., starch, sugar and ethanol (Byju and George., 2005). The main nutrients in sweet potato tubers are carbohydrates (15-28\% starch and 3-6\% Polysaccharides (Harvat et al., 1991). The sweet potato plant needs many studies that work to prolonging the period of crop displaying in the market without the occurrence of damage to the tuber roots and this requires studying the suitable planting dates for crop to appear in successive periods and also studying the nature of nutrition that works to increase the quality and increase the hardness of cells against external factors such as heat, moisture, light, pathogens, and internal factors such as low quality, internal decomposition and increased loss rate, and this requires studying the optimal storage methods that preserve the sweet potato crop for as long as possible. Planting dates play an important role in the growth of plants and increase the productivity of vegetables and crops because of the availability of appropriate temperatures for growth and yield, which leads to an increase in the total return or profit due to the increase in productivity, or crops may be planted at close dates to the appropriate dates with the aim of high prices and return (Sandhu et al., 2014 and Dash et al., 2018). Potassium is an essential nutrient for plants that plays an important role in plant growth and development and in photosynthesis, increasing enzyme activity, improving carbohydrates, protein and fat synthesis, transporting sugars, and working on cell and tissue stiffness against pests and diseases (Dakhil et al., 2011). On the other hand, Calcium is one of the essential nutrients for plants and plays an important role in building the plasma membranes of plants as it contributes to maintaining the stability of the cell membrane and wall surlier (Marschner, 1995). The importance of both calcium and magnesium is due to the interaction with pectic acid and the formation of the middle plate in the plant, which increases the carrying capacity of the tuber roots to increase the storage of starchy materials (Helal and AbdEl-hady, 2015). Foliar application of nutrients has many advantages over ground addition and is more economical than soil application or root application due to the higher degree of nutrients applied, which makes the nutrients more efficient and may also overcome the problem of ground nutrient uptake (Blachinski et al., 1996). Recently, there has been much interest in foliar fertilization of vegetables and crops due to the high cost of soil fertilizers, and the availability of new formulations of compounds with high absorption efficiency for the plant (Hiller, 1995). Therefore, the objective of this work was to study impact of planting dates and spraying with some macro elements on growth, yield, storage capacity and shelf life (prolonging the period of crop displaying in the market) of sweet potato.

\section{Materials and Methods}

A field experiment was conducted during two agricultural seasons of 2016 and 2017 at the Vegetable Research Farm of Kaha, Horticultural Research Institute, Agricultural Research Center, Giza Governorate, Egypt, under the conditions of clay soil, to study the effect of planting dates and spraying with some macro elements on growth, yield, storage capacity and shelf life (prolonging the period of crop displaying in the market) of sweet potato (Ipomoea batatas, L .) cv. Menoufia 6.

\subsection{Experimental Design:}

The experiment was distributed in the split-plot system with three replicates. Each experimental plot consisted of five ridges ( $5 \mathrm{~m}$ length $\mathrm{x} 0.75 \mathrm{~m}$ wide) and the area of the experimental unit was $18.75 \mathrm{~m}^{2}$, whereas; one ridge was left without planting as a guard ridge between plots to avoid the interference of various treatments. The cultivation was done by stems cuttings at three planting dates, i.e. $1^{\text {st }}$ April, $1^{\text {st }}$ June and $1^{\text {st }}$ August of both 2016 and 2017. The harvest took place after 130 days of planting for all the tested dates. The experiment included 12 treatments (three planting dates $\times$ four foliar feedings. The treatments were arranged at a split plot with three replicates as follows.

a) Planting dates in main-plot as:

$1^{\text {st }}$ April, $1^{\text {st }}$ June and $1^{\text {st }}$ August of both seasons

b) Foliar feeding with fertilizer elements in sub-plot as:

1. Potassium sulfate ( $48 \%$ potassium) at a concentration of $2500 \mathrm{ppm} \mathrm{K}_{2} \mathrm{O}$

2. Magnesium sulfate (10\% magnesium) at a concentration of $1500 \mathrm{ppm} \mathrm{Mg}$ 
3. Calcium nitrate $(17 \%$ calcium $)$ at a concentration of $2000 \mathrm{ppm} \mathrm{Ca}$

4. Control treatment (tap water).

The plants were sprayed 5 times, where the first treatment started in the 5th week after sowing and repeated each 15 days interval until the $13^{\text {th }}$ week. All the treatments were fertilized with the recommendation rates of NPK, Calcium superphosphate $\left(15.5 \% \mathrm{P}_{2} \mathrm{O}_{5}\right)$ was added once before planting as a source of phosphorus. Both ammonium nitrate $(33.5 \% \mathrm{~N}$, as nitrogen source) and potassium sulphate $\left(48 \% \mathrm{~K}_{2} \mathrm{O}\right.$, as a source of potassium) were applied in four constant doses (the extra nitrogen applied in the $\mathrm{Ca}$ treatment was balanced by reducing the ammonium nitrate application at side dressing). The other cultural practices were applied according to the recommendations of the Egyptian Agricultural Ministry for all treatments. Soil samples analyses were carried out according to the procedures described by Jackson, (1973) and the average of the obtained data are shown in Table 1.

Table 1: Physical and chemical properties of the experimental soil.

\begin{tabular}{cccccc}
\hline \multicolumn{2}{c}{ Physical properties } & \multicolumn{3}{c}{ Chemical properties } \\
\hline Items & $\mathbf{2 0 1 6}$ & $\mathbf{2 0 1 7}$ & Items & $\mathbf{2 0 1 6}$ & $\mathbf{2 0 1 7}$ \\
\hline Sand \% & 20.05 & 19.99 & Available N (ppm) & 80.63 & 78.22 \\
Silt \% & 18.97 & 19.11 & Available P (ppm) & 5.07 & 4.97 \\
Clay \% & 60.33 & 61.45 & Available K (ppm) & 209.17 & 210.53 \\
Texture class & Clay loam & pH & 7.65 & 7.55 \\
\hline
\end{tabular}

\subsection{Recorded data}

\subsubsection{Vegetative growth parameters:}

Measurements of vegetative growth were taken after 100 days of planting. Five plants were randomly selected to determine the average plant height, number of branches, fresh and dry weight of the plant

\subsubsection{Yield and its components:}

At harvest date (130 days of planting), crop samples were randomly taken up to record root length, number of roots, average fresh weight of root, fresh weight of roots per plant, Total yield (ton/fed), marketable yield and non-marketable crop.

\subsubsection{Chemical constituents:}

- Total nitrogen was determined according to the modified Kjeldahl method by Horneck and Miller (1998).

- Phosphorous was determined according to Watanabe and Olsen (1965) method.

- Potassium percentage was determined using the Flame Photometer according to Brown and Lilleland (1946).

- $\mathrm{Ca}$ and $\mathrm{Mg}$ were determined by atomic absorption spectrophotometer according to A.O.A.C. (1990).

- Total protein was calculated by a conversion factor $(\mathrm{N} \times 6.25)$ as described by Pregl (1945).

\subsubsection{Curing of tubers:}

At the time of harvest, $15 \mathrm{~kg}$ tuberous roots were taken from each treatment after cleaning of the suspended soil, all roots were sorted and damaged roots were disposed. The curing was carried out by laying out the tubers carefully and allowing them dry for 10 days to 2 weeks in a warm location (26 to $29^{\circ} \mathrm{C}$ ) with a humidity level of $80-90$ percent. Fresh weight data were taken after curing.

\subsubsection{Tubers storability}

The roots were packed into perforated numbered bags and stored in a complete random way in three replications for 4 months (120 days). All treatments were stored in a prepared warehouse, in which the complete cleanliness of pathogens and insects at normal room temperature so that there is free flow of air through the tubers to minimize heat buildup which can result into soft rots. All the replicates were checked every month to calculate the percentage of weight loss at 30,60, 90, 120 days of storage as well as decay percentage as average of all storage period, in both seasons. 
Weight loss percentage was estimated by to the following equation:

$$
\text { Weight loss } \% \frac{\text { Initial tuber weight-tuber weight at sampling date }}{\text { Initial tuber weight }} \times 100
$$

- The percentage of decayed roots in relation to the total number of roots was calculated according to the following formula:

$$
\text { Decay roots } \% \frac{\text { Number of decayed roots }}{\text { Total numbers of tubers }} \times 100
$$

\subsection{The economic analysis:}

The sweet potato market price (in Egypt) as showing in Table 2, where the market prices different from month to other, were used to estimate the total economic Monetary value (MV) according to Gomez and Gomez (1984), based on the storage periods as following:

\section{Monetary value $(\mathrm{MV})=$ yield $\times$ market price of $\operatorname{root}(\operatorname{ton} / \mathbf{f e d})$}

Table 2: Sweet potato market price in Egypt at different harvest times of the three planting dates (PD) and after storage periods (SP), 2017

\begin{tabular}{cccccc}
\hline \multirow{2}{*}{ Item } & \multicolumn{5}{c}{ Egyptian market prices (L.E.) } \\
\cline { 2 - 6 } & At harvest time & $\mathbf{3 0}$ days SP & 60 days SP & 90 days SP & 120 days SP \\
\hline $\mathbf{1}^{\text {st }}$ April & 1000 & 1000 & 1100 & 1300 & 1500 \\
$\mathbf{1}^{\text {st }}$ June & 1100 & 1300 & 1500 & 1800 & 2000 \\
$\mathbf{1}^{\text {st }}$ August & 1500 & 1800 & 2000 & 2000 & 1900 \\
\hline
\end{tabular}

\subsection{Statistical analysis:}

All recorded data were subjected to analysis of variance procedures and treatment means were compared with L.S.D. as described by Gomez and Gomez (1984). Statistical analysis was performed by MSTATC version 4 computer program.

\section{Results and Discussion}

\subsection{Vegetative growth parameters:}

\subsubsection{Effect of planting dates:}

The results illustrated in Fig. 1 indicate that the planting dates positively affected the studied vegetative growth characteristics (plant height, number of branches, fresh and dry weight of the plant) as the first planting date at $1^{\text {st }}$ April recorded significantly the highest values for all vegetative traits followed by the $2^{\text {nd }}$ date ( $\left.1^{\text {st }} J u n e\right)$ and $1^{\text {st }}$ Agust (third date), in descending during the study seasons.

\subsubsection{Effect of foliar spraying:}

The results presented in Fig. 2 show that the vegetative growth characteristics (plant height, number of branches, fresh and dry weight of plant) were strongly influenced by foliar spraying with some elements.

Potassium foliar spray surpassed the other treatments in all the studied traits during the two seasons of study except for the plant height and the fresh weight of the canopy in which the foliar spray with the calcium element was the highest effect with no significant differences between $\mathrm{K}, \mathrm{Ca}$ and $\mathrm{Mg}$ for fresh weight of canopy in $1^{\text {st }}$ season and between $\mathrm{K}$ and $\mathrm{Ca}$ for both plant length and fresh weight of canopy in $2^{\text {nd }}$ season, while the control treatment recorded the lowest values obtained in all the studied vegetative growth characteristics during the two study seasons. 


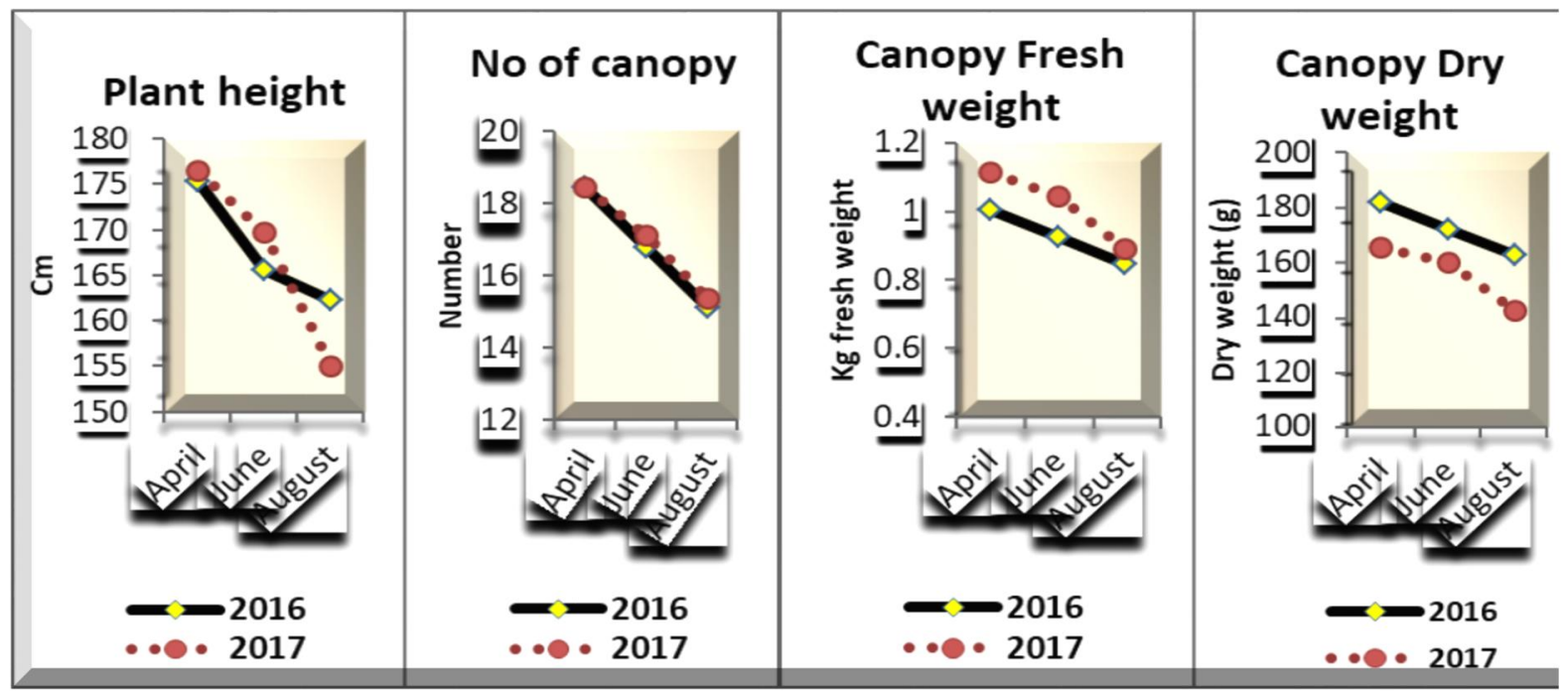

Fig. 1: Vegetative growth characters of sweet potato plants as affected by planting date.

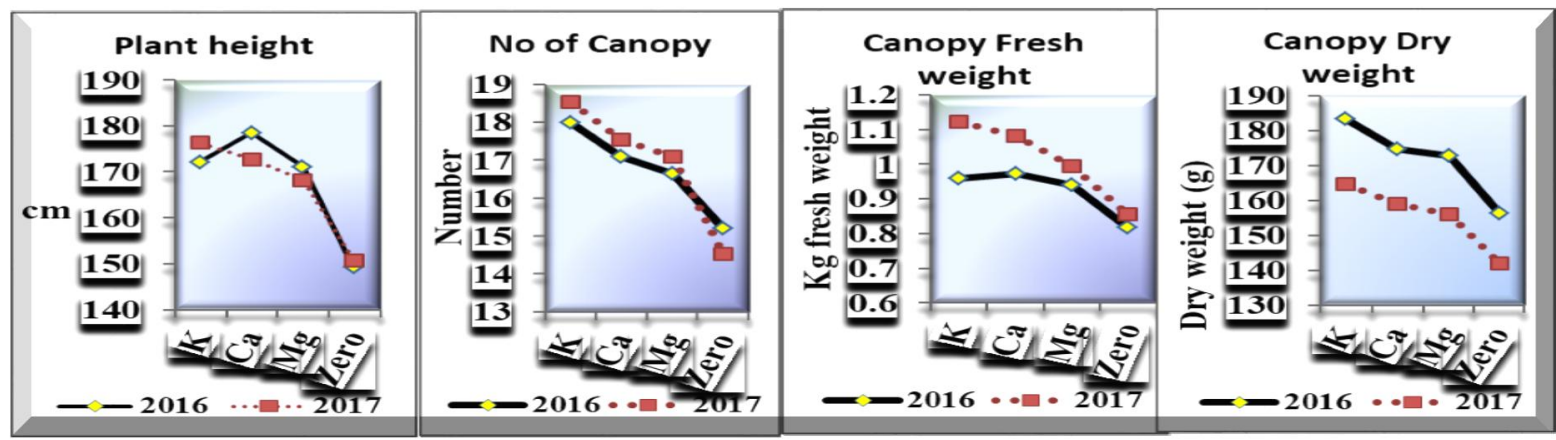

Fig. 2: Vegetative growth characters of sweet potato plants as affected by nutrients foliar spray

\subsubsection{Effect of the interaction:}

The results shown in Table 3 indicate that the vegetative growth characteristics were positively affected by the interaction of three planting dates and foliar spraying with each of potassium, calcium and magnesium and this led to a positive interaction and significant differences between the treatments. The foliar spray with the potassium element interacted with $1^{\text {st }}$ planting date led to significant differences and clear superiority over the rest of the other factors and the same effect was observed during the three dates, while calcium foliar spray showing an increase in most of the vegetative growth characteristics compared to magnesium foliar spray during the three planting dates, which recorded significant values, but they were less compared to potassium and calcium. The control treatment recorded the lowest values obtained in all of these characteristics during the three appointments throughout the study years.

The increase in growth during the first and second dates due to the compatibility of climatic factors (temperature and humidity) may be due to the optimum temperature for the cultivation process and the beginning of growth, while the relatively low growth may be due in the third season due to high temperatures at the beginning of the plant's life and lower temperatures at the end of the plant's life. These results are consistent with the results obtained by Nisha, (2020). The increase in the characteristics of green growth may be attributed to the main role of calcium, as it is a necessary nutrient in plants and participates in many physiological processes inside the plant. These results agreement with Mengel and Kirkby (2001) who mentioned that calcium has an important role within the plant as it works to stabilize cells and El-Hadidi., et al. (2017) stated that the foliar spray on the sweet potato plant with calcium gave the highest values of the vegetative growth parameters and this shows the importance of providing plants with calcium to improve vegetative growth and may be due to absorbing nutrients and improving the growth process. 
Table 3: Vegetative growth characters of sweet potato plants as affected by planting date and macronutrients foliar spray interaction.

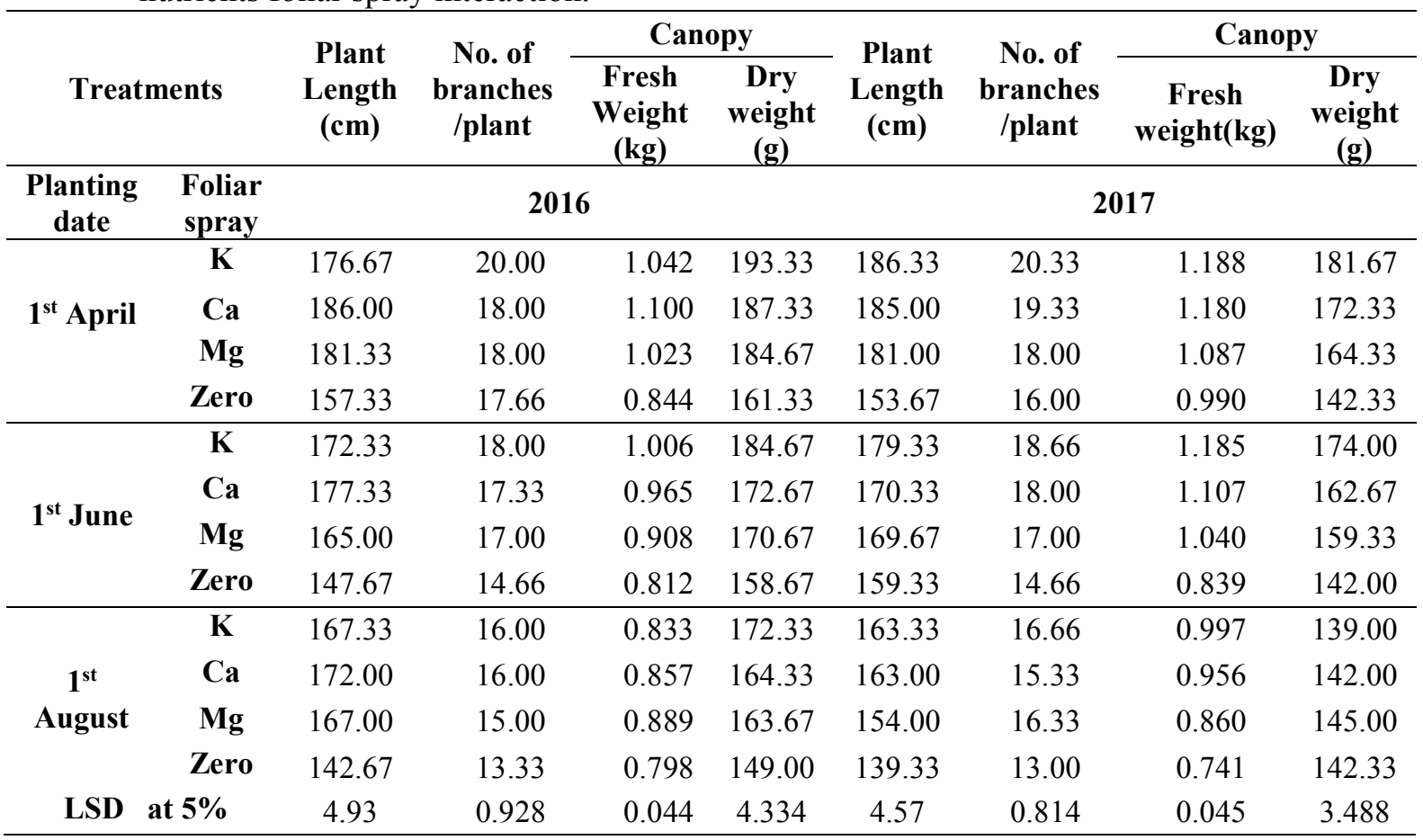

The increase in the vegetative growth characteristics of plants that have been sprayed with potassium may be attributed to the effective role of potassium in feeding plants, as it enhances the activity of enzymes and increases the speed of interaction and has a major role in the process of respiration and activation of the cytoplasm. It may also be due to the positive role of potassium in the representation of nitrogenous compounds and the conversion of amino acids into proteins through its entry into the formation of the peptide bond or due to its indirect role in helping the iron element to play its role in the formation of chlorophyll, which is the basis of the photosynthesis process in plants (Sangakkara et al., 2000). The results are agreement with Romheld and Kirkby (2010) and Marschner (2012) who mentioned that potassium $\mathrm{K}$ plays an important role in regulating water and gas exchange and carbon dioxide uptake, increases osmotic pressure and the level of swelling in plant cells and works to increase the surface of roots and increase absorption in plants.

\subsection{Yield and its components}

\subsubsection{Effect of planting dates:}

Fig. 3 shows that the yield and its components (root length, number of roots, average fresh weight of the root, roots fresh weight per plant, total yield per feddan, marketable yield, and non-marketable yield) have a significant effect on the different three planting dates $\left(1^{\text {st }}\right.$ April date, $1^{\text {st }}$ June and $1^{\text {st }}$ August) and the first planting date surpassed the rest of the other dates followed by the second one $\left(1^{\text {st }}\right.$ June) and the $3^{\text {rd }}$ one (early August) in descending order during both seasons.

\subsubsection{Effect of foliar spray:}

The results presented in Fig. 4 indicate that foliar spraying with (potassium, calcium, and magnesium) resulted in significant differences in most of the yield characteristics and its components (root length, number of roots, average of root fresh weight, fresh weight of roots per plant and total yield per feddan as well as both Marketable and non-marketable yield/fed) compared to the control treatment which recorded the lowest values in all the characteristics of the yield and its components. Spraying plants with potassium element led to desirable an increase in most of the characteristics of yield traits, followed by calcium, magnesium and control in descending order for each of root length, number of roots per plant and roots weight per plant in both seasons as well as average root weight, total roots yield and marketable yield in $1^{\text {st }}$ season. 

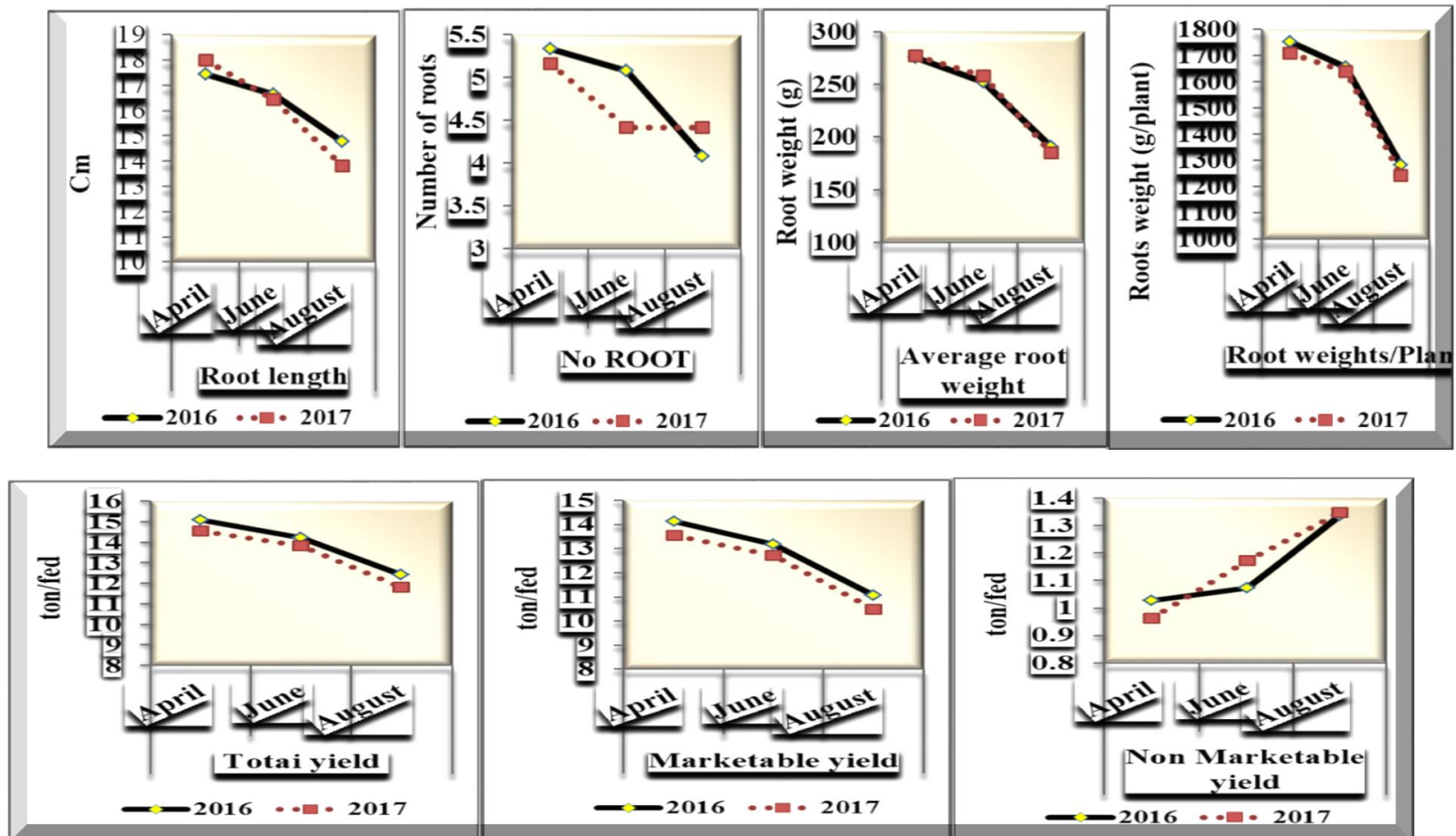

Fig. 3: Yield and its components of sweet potato plants as affected by planting dates
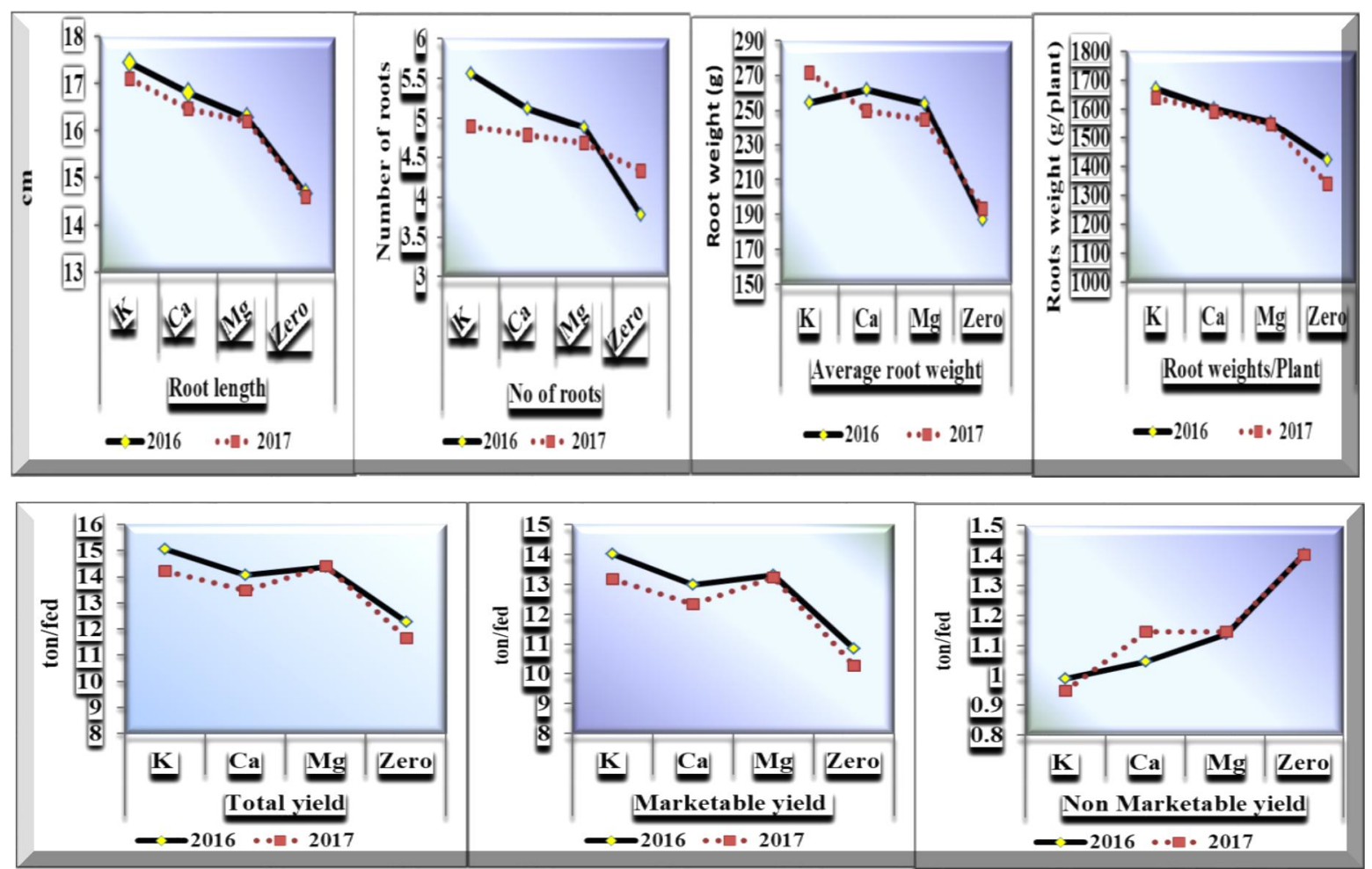

Fig. 4: Yield and its components of sweet potato plants as affected by nutrients foliar spray

\subsubsection{Effect of the interaction:}

Results presented in Table 4 indicate that the combination of planting dates and foliar spray with nutrients (potassium, calcium and magnesium) led to a significantly desirable interaction in all the characteristics of yield and its components at both seasons except number of roots/plant in $2^{\text {nd }}$ season. Foliar spray with potassium resulted in a significant increase and a clear superiority over other treatments for all traits compared to the control during the three planting dates in the two agricultural 
seasons, except root length $\left(1^{\text {st }} \mathrm{PD}\right)$ and both total yield and marketable yield in $1^{\text {st }}$ and $3^{\text {rd }} \mathrm{PD}$ in which magnesium spray was superior than potassium spray with slightly differences between both treatments. Increases of the roots yield during the first and second dates may be attributed to the availability of a suitable climate of temperature and humidity during the period of plant growth, which led to the formation of a strong vegetative group that contributed to the activation of the photosynthesis process and the formation of an excess of carbohydrates over the plant's need.

Table 4: Yield and its components of sweet potato plants as affected by planting date and macro nutrients foliar spray interaction.

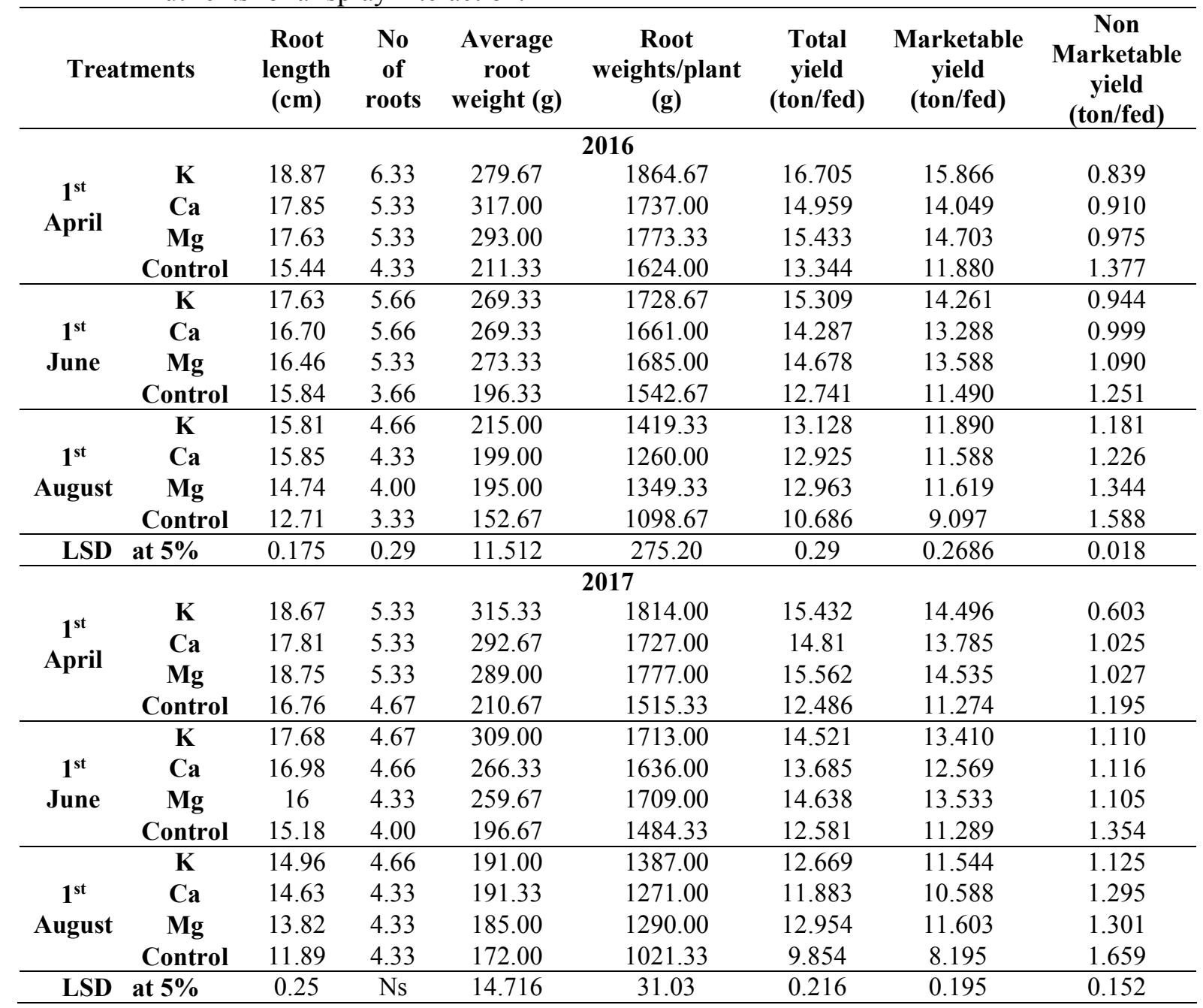

Increase the total yield and improve the quality characteristics are agreed with Martin (1987), Mishra et al. (2019) and Allolli et al (2011). They stated that vegetative growth was obtained above the soil surface and the highest yield was obtained from the tuberous roots of the plants that were planted on July $30^{\text {th }}$, this may be due to the compatibility of climatic conditions with needs of sweet potato plants. On the other hand, increase of total sweet potato production can be attributed to the foliar fertilization of potassium, magnesium and calcium positive interaction between them led to an increase in the efficiency of photosynthetic pigments which increase the vegetative growth, increase carbohydrates and their accumulation in the tuber roots, and improve the characteristics of the crop and its components. Similar results were reported by Gowda et al. (1990), Mishra et al. (1992), El-Denary (1998), George et al. (2002), Talukder et al. (2009), El-Sawy (2011) and El-Hadidi, et al. (2017). They found that the foliar spray with the element of magnesium increased the yield of tubers and the total yield per feddan, this may be because of the magnesium enhances the chlorophyll concentration and increases leaf area and number of leaves, and this increases production and total yield. It may be due to the role of potassium, calcium and magnesium inside the plant, where potassium activates enzymes and 
carries energy and has a relationship with the formation of carbohydrates in the plant and has a fundamental role in transporting compounds to their storage places and that calcium works to regulate the implementation of membranes, regulate the metabolism process, and control respiration. Magnesium stimulates nutrient absorption and carbohydrate formation and accelerates enzymatic processes (Byju and George, 2005).

\subsection{Chemical Contents}

\subsubsection{Effect of planting dates:}

Data illustrated in Fig. 5 shows that the chemical content of potato plants recorded significant differences among planting dates ( $1^{\text {st }}$ April, $1^{\text {st }}$ June and 1st August) and this was positively reflected on the chemical components of the roots. Early April surpassed the other planting dates, followed by June and August, in descending order for chemical contents of the sweet potato roots, during the two study seasons.
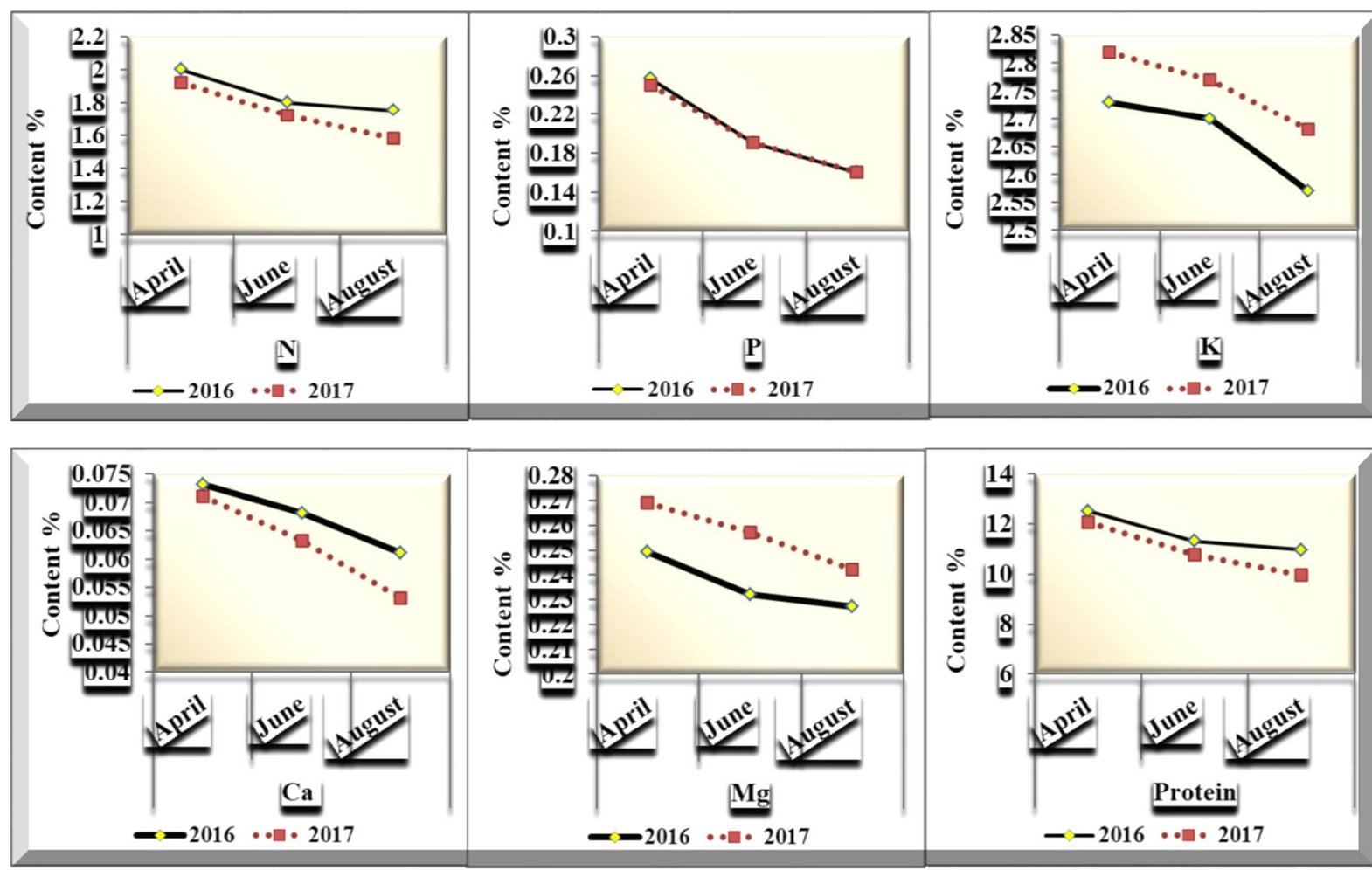

Fig. 5: Chemical Contents of sweet potato roots as affected by planting dates

\subsubsection{The effect of foliar spray:}

The results (Fig. 6) indicate that spraying plants with potassium, calcium and magnesium resulted in significant differences for most characteristics of the chemical content in the roots of the tested plants, as the content of elements (nitrogen, phosphorous and potassium, as well as protein) increased when plants treated with potassium foliar spray, and recorded the highest values obtained in most of the tested chemical characteristics during the different planting dates in the agricultural seasons, while the treatment of plants with foliar spraying with the element calcium and magnesium recorded the highest significant increase in the calcium and magnesium content of roots, respectively.

\subsubsection{Interaction effect:}

The results presented in Table 5 indicate that the interaction between foliar spraying with fertilizer elements (potassium, calcium and magnesium) and planting potato plants at three different dates resulted in significant differences in the content of potato roots of the nutrients. Potassium spray was superior to other foliar spray nutrients where the plants recorded the highest values for $\mathrm{N}, \mathrm{P}, \mathrm{K}$ and protein under the three planting dates during the two seasons. 

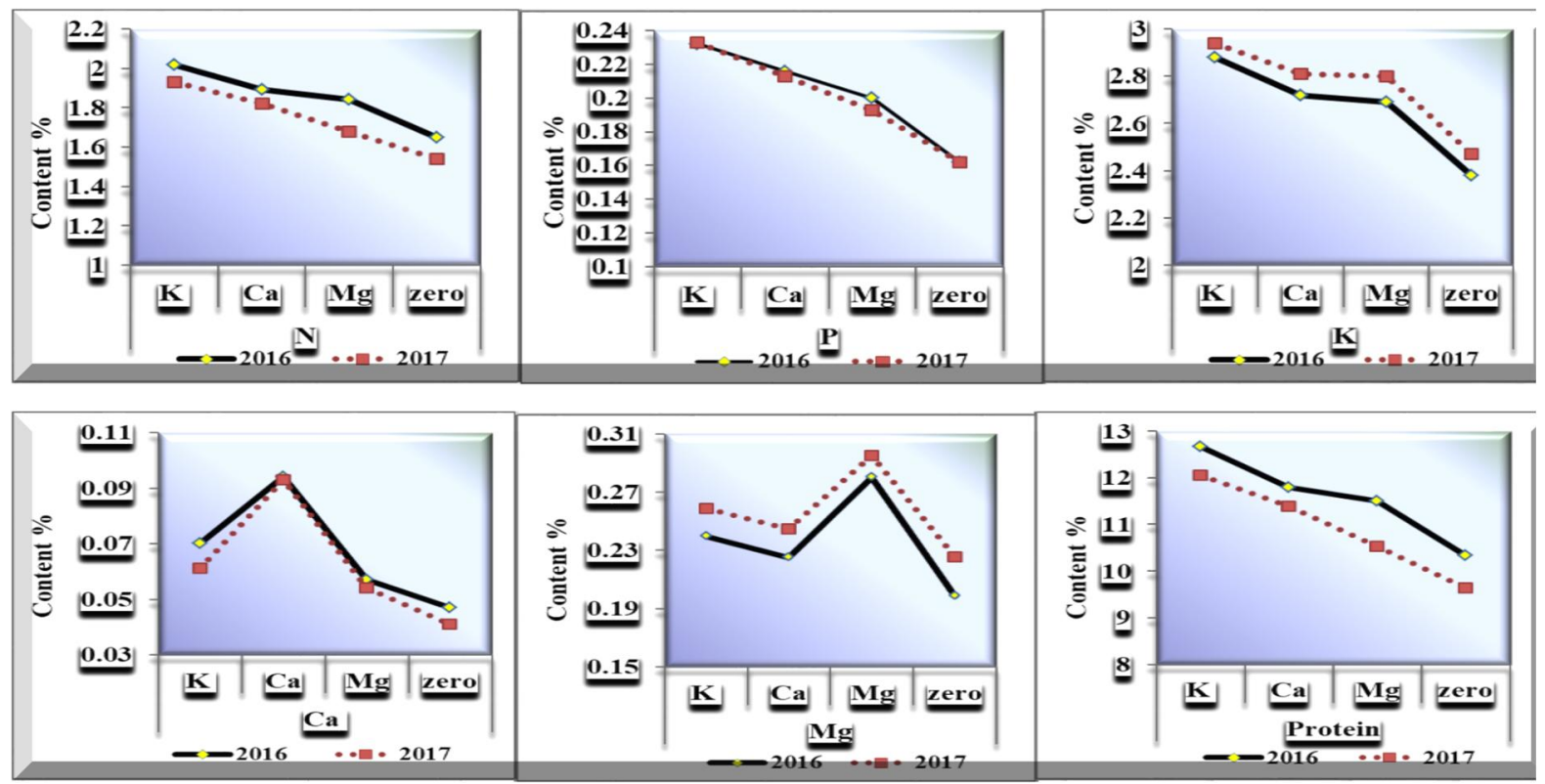

Fig. 6: Chemical contents of sweet potato roots as affected by macro nutrients foliar spray

Table 5: Chemical contents of sweet potato roots as affected by planting date and macro nutrients foliar spray interaction.

\begin{tabular}{|c|c|c|c|c|c|c|c|}
\hline \multicolumn{2}{|c|}{ Treatments } & \multirow{2}{*}{$\begin{array}{c}\mathbf{N} \text { \% } \\
2.1\end{array}$} & \multirow{2}{*}{\begin{tabular}{|c|}
$\mathbf{P} \%$ \\
0.303 \\
\end{tabular}} & \multirow{2}{*}{$\begin{array}{c}\begin{array}{c}K \% \\
2016\end{array} \\
3\end{array}$} & $\mathrm{Ca} \%$ & Mg \% & Protein \% \\
\hline \multirow{4}{*}{$1^{\text {st }}$ April } & $\mathbf{K}$ & & & & 0.087 & 0.255 & 13.14 \\
\hline & $\mathrm{Ca}$ & 2.06 & 0.28 & 2.76 & 0.091 & 0.239 & 12.87 \\
\hline & Mg & 1.95 & 0.253 & 2.69 & 0.065 & 0.294 & 12.22 \\
\hline & Control & 1.88 & 0.193 & 2.48 & 0.048 & 0.211 & 11.77 \\
\hline \multirow{4}{*}{$1^{\text {st }}$ June } & $\mathbf{K}$ & 2.05 & 0.213 & 2.94 & 0.07 & 0.242 & 12.93 \\
\hline & $\mathrm{Ca}$ & 1.77 & 0.2 & 2.72 & 0.098 & 0.213 & 11.09 \\
\hline & Mg & 1.79 & 0.186 & 2.80 & 0.054 & 0.274 & 11.20 \\
\hline & Control & 1.59 & 0.163 & 2.35 & 0.051 & 0.2 & 9.93 \\
\hline \multirow{4}{*}{$\begin{array}{c}1^{\text {st }} \\
\text { August }\end{array}$} & $\mathbf{K}$ & 1.91 & 0.18 & 2.69 & 0.053 & 0.224 & 11.93 \\
\hline & $\mathrm{Ca}$ & 1.83 & 0.17 & 2.70 & 0.095 & 0.224 & 11.45 \\
\hline & Mg & 1.77 & 0.16 & 2.59 & 0.053 & 0.273 & 11.10 \\
\hline & Control & 1.48 & 0.13 & 2.32 & 0.041 & 0.187 & 9.28 \\
\hline \multirow[t]{2}{*}{ LSD } & at $5 \%$ & 0.09 & 0.01 & 0.071 & 0.003 & 0.009 & 0.55 \\
\hline & & & & 2017 & & & \\
\hline \multirow{4}{*}{$1^{\text {st April }}$} & $\mathbf{K}$ & 2.09 & 0.306 & 3.07 & 0.077 & 0.275 & 13.06 \\
\hline & $\mathrm{Ca}$ & 1.99 & 0.27 & 2.76 & 0.095 & 0.259 & 12.47 \\
\hline & Mg & 1.88 & 0.233 & 2.83 & 0.062 & 0.306 & 11.74 \\
\hline & Control & 1.74 & 0.193 & 2.62 & 0.05 & 0.238 & 10.89 \\
\hline \multirow{4}{*}{$1^{\text {st }}$ June } & $\mathbf{K}$ & 1.92 & 0.213 & 2.91 & 0.065 & 0.266 & 12.04 \\
\hline & $\mathrm{Ca}$ & 1.84 & 0.2 & 2.81 & 0.095 & 0.236 & 11.49 \\
\hline & Mg & 1.67 & 0.186 & 2.82 & 0.052 & 0.296 & 10.43 \\
\hline & Control & 1.45 & 0.163 & 2.55 & 0.041 & 0.229 & 9.10 \\
\hline \multirow{4}{*}{$\begin{array}{c}1^{\text {st }} \\
\text { August }\end{array}$} & $\mathbf{K}$ & 1.77 & 0.18 & 2.85 & 0.042 & 0.236 & 11.08 \\
\hline & $\mathrm{Ca}$ & 1.63 & 0.17 & 2.87 & 0.09 & 0.239 & 10.20 \\
\hline & Mg & 1.51 & 0.16 & 2.76 & 0.048 & 0.284 & 9.43 \\
\hline & Control & 1.42 & 0.13 & 2.25 & 0.031 & 0.211 & 8.92 \\
\hline LSD & at $5 \%$ & 0.079 & 0.011 & 0.057 & 0.005 & 0.006 & 0.498 \\
\hline
\end{tabular}

First of April planting interacted with Potassium spray exhibited the highest contents. These results are in agreement with those reported by Sandhu et al. (2014) and Dash et al. (2018). The planting dates had a significant effect on the chemical content of the tuberous roots, and this may be due to the 
interaction of the elements with the planting dates, especially the first and second dates with the organic compounds inside the plant and the increase in their content in plant tissues, this may be due to the improvement in environmental conditions resulting from the appropriate climate for agricultural dates and the improvement of nutrient absorption from the soil, as this resulted in an increase in the content of the tuber roots of the mineral elements (N, P, K, Ca, Mg and protein). Mansour and Abu El-Fotoh (2018) mentioned that there are significant differences in the content of potato plants from the chemical elements due to the different planting dates. The increase in the content of the tuber roots of the mineral elements may be attributed to the common interaction resulting from spraying with nutrients between potassium, calcium and magnesium where the content of nitrogen, phosphorous, potassium, calcium and magnesium increased.

Also, Ozgen et al. (2006), Hamdi et al. (2015), Hilal and AbdEl-hadi (2015) and El-Hadidi, et al. (2017) stated that the foliar spray with both Calcium and magnesium led to the presence of a common positive reaction on the starch and protein content and a significant increase in the concentrations of $\mathrm{N}$, $\mathrm{Ca}$ and $\mathrm{Mg}$ in leaves and tubers and increasing roots mineral elements of $\mathrm{N}, \mathrm{P}, \mathrm{K}, \mathrm{Ca}$ and $\mathrm{Mg}$ due to the foliar application of potassium, calcium, and magnesium to improve the absorption of elements and increase their content within the plant and to play their role in all biological, physiological and biochemical processes.

\subsection{Storage of tuber roots}

\subsubsection{Effect of planting dates:}

Figure 7 shows that the storage periods were significantly influenced by the different planting dates except 90 days of April planting in which insignificant differences among the three planting dates. $3^{\text {rd }}$ date (early August) recorded the lowest percentage loss in weight and decay followed by $2^{\text {nd }}$ date (June planting) and early April in both seasons. In this regard, the third planting date recorded the lowest values in the percentage of loss, followed by the second planting date, followed by the first planting date in descending order.

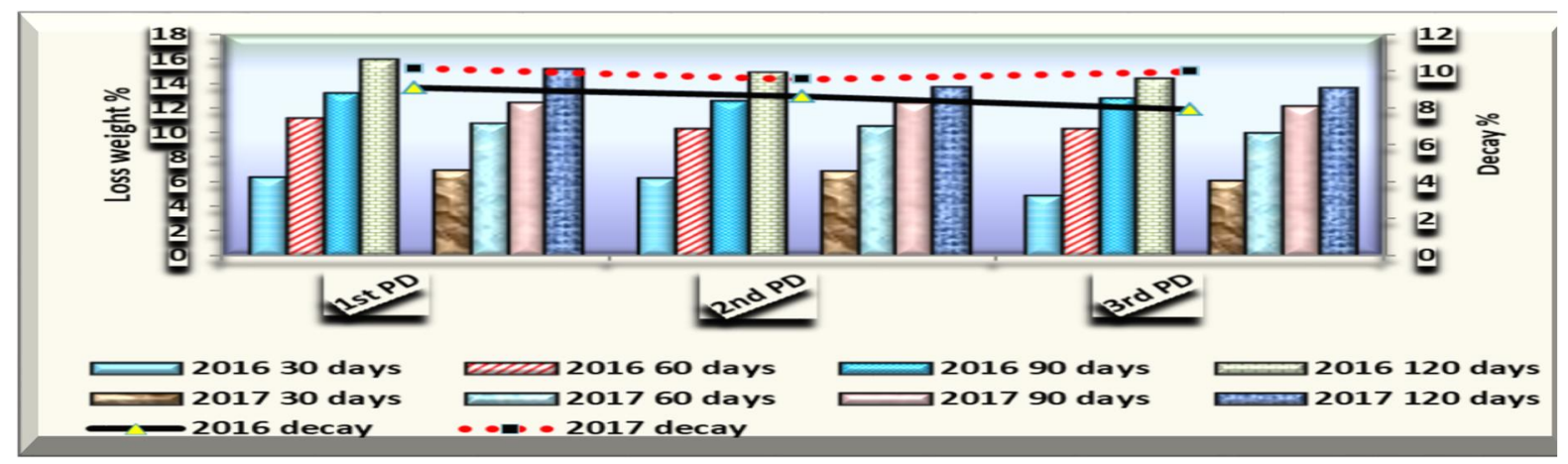

Fig. 7: Storage periods of sweet potato roots as affected by planting dates (PD) in average of both seasons.

\subsubsection{Effect of foliar spray.}

The results illustrated in Fig. 8 indicate that there are significant differences among the three spraying treatments. Control treatment recorded the highest values obtained in the percentage of loss or in the proportion of decay compared to other treatments that were subject to the foliar application of potassium, calcium or magnesium, and the desirable lowest values were obtained with calcium spray followed by magnesium or potassium alike with no significant differences between ( $\mathrm{K}$ and $\mathrm{Ca}$ ), ( $\mathrm{K}$ and $\mathrm{Mg}$ ) and ( $\mathrm{Ca}$ and $\mathrm{Mg}$ ) at 30,60 and 120 days for weight loss percentage, respectively in both seasons as well as (K and $\mathrm{Mg})$ for weight loss percentage at 90 days and decay in $1^{\text {st }}$ and $2^{\text {nd }}$ season, respectively. whether the spraying any element led to positive effects in reducing the percentages of weight loss and decay in tuber roots stored in the room (natural) temperature and humidity for four consecutive months compared to the control treatment that recorded the highest values in the loss percentage during the storage periods during the two studied seasons. 

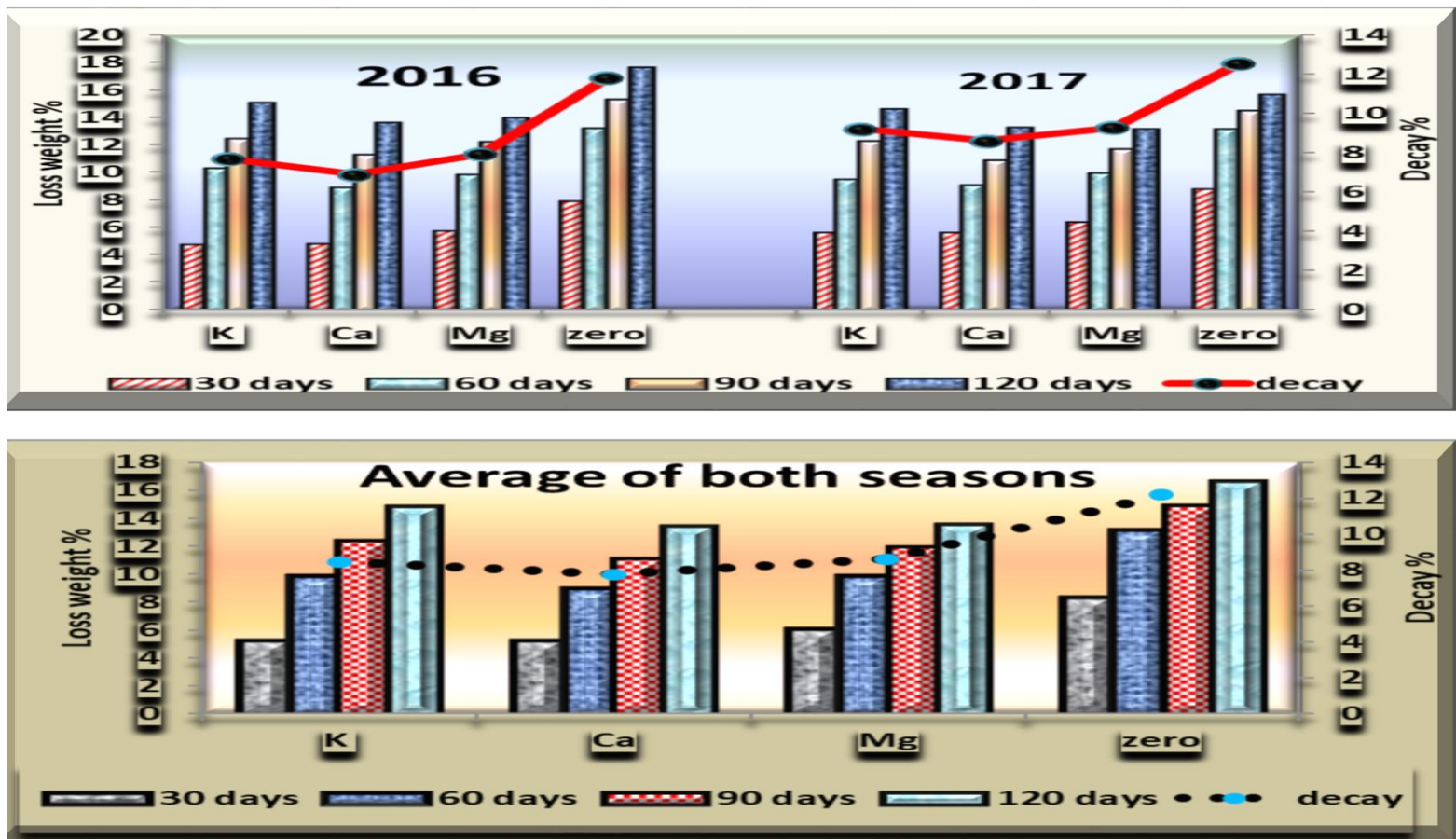

Fig. 8: Storage periods of sweet potato roots as affected by macro nutrient foliar spray in the two seasons and average of both seasons.

\subsubsection{Interaction effect:}

The results presented in Table 6 and Fig. 9 show that planting dates interacted with foliar spraying with each of potassium, calcium and magnesium led to significant differences through the different storage periods, where calcium foliar spray (over all storage periods) resulted in the lowest percentage of weight loss and decay in $2^{\text {nd }}$ (June) and $3^{\text {rd }}$ (August) planting date, respectively compared to the rest of other treatments followed by $\mathrm{Ca}$ treatment interacted with $1^{\text {st }}$ date in 90 days storage period of both seasons with no significant differences between $\mathrm{Ca}$ and $\mathrm{Mg}$ foliar spray interacted with any planting date and among the three nutrients interacted with $2^{\text {nd }}$ planting date at 120 days storage period of both seasons. On the contrary, the greatest weight loss and decay percentage of tubers were obtained in untreated control. The positive effect of $\mathrm{K}, \mathrm{Ca}$ and $\mathrm{Mg}$ and its combinations treatments on sweet potato roots yield components could be interpreted by multiple physiological functions to each element (ElZohiri and Youssef, 2015).

Table 6: Weight loss and decay percentage of sweet potato as affected by planting date and macro nutrients foliar spray interaction in both seasons

\begin{tabular}{|c|c|c|c|c|c|c|c|c|c|c|c|c|c|}
\hline \multirow{2}{*}{\multicolumn{2}{|c|}{ Treatments }} & \multicolumn{5}{|c|}{ Weight loss \% at storage periods: } & \multirow[b]{2}{*}{ Decay } & \multicolumn{5}{|c|}{ Weight loss \% at storage periods: } & \multirow[b]{2}{*}{ Decay } \\
\hline & & $\begin{array}{c}30 \\
\text { days }\end{array}$ & $\begin{array}{c}60 \\
\text { days }\end{array}$ & $\begin{array}{c}90 \\
\text { days }\end{array}$ & $\begin{array}{c}120 \\
\text { days }\end{array}$ & Mean & & $\begin{array}{c}30 \\
\text { days }\end{array}$ & $\begin{array}{c}60 \\
\text { days }\end{array}$ & $\begin{array}{c}90 \\
\text { days }\end{array}$ & $\begin{array}{c}120 \\
\text { days }\end{array}$ & Mean & \\
\hline Main & Sub & & & & 2016 & & & & & & 2017 & & \\
\hline & $\mathbf{K}$ & 5.31 & 11.37 & 12.78 & 16.10 & 11.39 & 8.63 & 6.26 & 10.40 & 12.22 & 15.78 & 11.17 & 9.57 \\
\hline $1^{\text {st }}$ & $\mathrm{Ca}$ & 5.36 & 9.37 & 11.48 & 14.07 & 10.07 & 7.04 & 5.90 & 8.74 & 10.77 & 14.48 & 9.97 & 8.67 \\
\hline \multirow[t]{2}{*}{ April } & Mg & 6.44 & 10.07 & 12.11 & 14.44 & 10.77 & 8.19 & 6.73 & 9.71 & 11.26 & 13.78 & 10.37 & 9.35 \\
\hline & Zero & 8.35 & 13.70 & 16.46 & 19.11 & 14.41 & 12.64 & 8.94 & 14.07 & 15.55 & 16.73 & 13. & 13.06 \\
\hline \multirow{4}{*}{ June } & $\mathbf{K}$ & 4.68 & 9.74 & 11.78 & 14.41 & 10.15 & 7.51 & 5.17 & 9.37 & 12.47 & 13.74 & 10.19 & 8.77 \\
\hline & $\mathrm{Ca}$ & 4.88 & 8.70 & 10.74 & 13.44 & 9.44 & 7.53 & 5.92 & 9.07 & 10.11 & 12.71 & 9.45 & 9.03 \\
\hline & Mg & 6.62 & 9.70 & 12.14 & 14.44 & 10.73 & 8.06 & 6.45 & 10.7 & 12.77 & 13.01 & 10.73 & 9.25 \\
\hline & Zero & 8.77 & 13.07 & 15.47 & 17.37 & 13.67 & 11.75 & 9.81 & 13.11 & 14.48 & 15.55 & 13.24 & 12.17 \\
\hline \multirow{4}{*}{$\begin{array}{c}1^{\text {st }} \\
\text { August }\end{array}$} & $\mathbf{K}$ & 4.38 & 9.77 & 12.81 & 14.73 & 10.42 & 6.90 & 5.60 & 8.77 & 12.18 & 14.41 & 10.24 & 8.29 \\
\hline & $\mathrm{Ca}$ & 4.23 & 8.70 & 11.74 & 13.37 & 9.51 & 6.34 & 5.06 & 9.41 & 11.77 & 12.63 & 9.72 & 8.46 \\
\hline & Mg & 4.18 & 9.77 & 12.44 & 13.03 & 9.86 & 7.54 & 6.04 & 9.40 & 11.11 & 12.70 & 9.81 & 9.12 \\
\hline & Zero & 6.65 & 12.81 & 14.07 & 16.40 & 12.48 & 11.07 & 7.57 & 12.37 & 13.47 & 14.74 & 12.04 & 11.39 \\
\hline \multicolumn{2}{|c|}{ LSD } & 0.46 & 1.11 & 1.21 & 1.51 & & 0.09 & 0.15 & 1.09 & 0.78 & 1.58 & & 0.18 \\
\hline
\end{tabular}



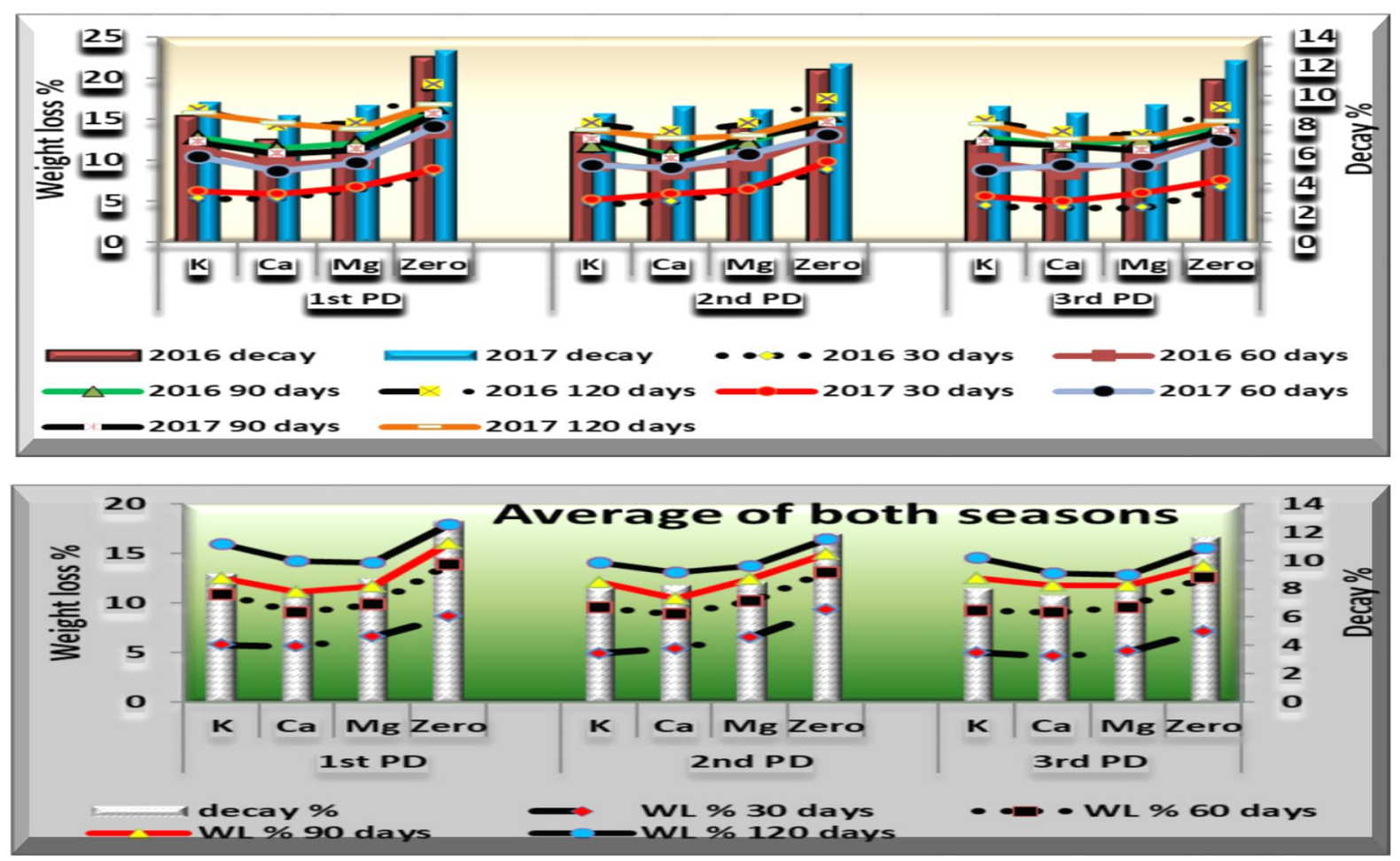

Fig. 9: Storage periods of sweet potato roots as affected by macro nutrient foliar spray in the two seasons and average of both seasons.

The increased storability of the tubers roots for storage may be due to the withstand of the roots to endure storage conditions due to the foliar spraying with the necessary elements such as calcium and magnesium, the occurrence of a interaction with pectic acid and the formation of calcium and magnesium pactites that work to stick cellulose chains together during the work of the cell walls, which leads to the preservation of the content of the compounds organic and moisture inside the roots and control of respiration. These results are in agreed with Marschner (2013), Graham (1983) and Banerjee et al. (2014). They mentioned that calcium has a major role in regulating metabolism, controlling respiration, mitigating the impact of environmental stresses and reducing the production of ethylene in plants.

\subsection{Economic study for sweet potato storage:}

Obtained data concerned with the effect of planting dates, nutrients foliar spray and their interaction on storage of marketable yield of sweet potato (Table 7, 8,9) and illustrated in Fig. 7,8, 9 revealed that marketable yield/fed have a significant effect with the different three planting dates $\left(1^{\text {st }}\right.$ April date, $1^{\text {st }}$ June and $1^{\text {st }}$ August) and the first planting date surpassed the rest of the other dates followed by $1^{\text {st }}$ June and early August in descending order during both seasons. On the other hand, foliar spraying with (potassium, calcium, and magnesium) resulted in significant differences in Marketable yield/fed compared to the control treatment which recorded the lowest values as discussed previously in Fig.4. Spraying plants with potassium element led to desirable an increase yield trait, followed by calcium, magnesium and control in descending order at harvest and all storage periods after takeaway the losses. As for the interaction effects, the combination of planting dates and foliar spray with nutrients led to a significantly desirable interaction in yield at both seasons. Foliar spray with potassium interacted with April planting date resulted in a significant increase and a clear superiority over other treatments, followed by calcium and magnesium compared to the control at harvest time and through the four storage periods during the three planting dates over two seasons. It is desirable to analyze the economic viability of storage on monetary basis following Gomez and Gomez (1984) formula. Monetary values of the marketable yield of sweet potato were calculated according to their market price (locally farmers price) as showing in Table 2, where the market prices different from month to other, in locally market for wholesale at the beginning of the harvest season (2017). 
Table 7: Marketable yield (ton/fed) as affected by planting dates, macro nutrients foliar spray and their interaction over both seasons

\begin{tabular}{|c|c|c|c|c|c|c|}
\hline \multirow{2}{*}{\multicolumn{2}{|c|}{ Item }} & \multirow{2}{*}{ at harvest } & \multicolumn{4}{|c|}{ After take away the losses } \\
\hline & & & 30 days & 60 days & 90 days & 120 days \\
\hline \multicolumn{7}{|c|}{ Planting dates (PD) } \\
\hline \multirow{2}{*}{\multicolumn{2}{|c|}{$\begin{array}{l}1^{\text {st }} \text { April } \\
1^{\text {st }} \text { June }\end{array}$}} & 13.823 & 12.903 & 12.312 & 12.049 & 11.671 \\
\hline & & 12.928 & 12.084 & 11.580 & 11.313 & 11.074 \\
\hline \multicolumn{2}{|c|}{$1^{\text {st }}$ August } & 10.765 & 10.178 & 9.675 & 9.424 & 9.257 \\
\hline \multirow{2}{*}{\multicolumn{2}{|c|}{$\mathbf{K}$}} & & Foliar sp & & & \\
\hline & & 13.578 & 12.869 & 12.232 & 11.898 & 11.559 \\
\hline \multicolumn{2}{|c|}{$\mathrm{Ca}$} & 12.645 & 11.985 & 11.507 & 11.240 & 10.943 \\
\hline \multicolumn{2}{|c|}{ Mg } & 13.264 & 12.457 & 11.951 & 11.676 & 11.464 \\
\hline \multicolumn{2}{|c|}{ Zero } & 10.537 & 9.659 & 9.148 & 8.964 & 8.780 \\
\hline \multicolumn{7}{|c|}{ PD $\times$ FS interaction } \\
\hline \multirow{4}{*}{$1^{\text {st }}$ April } & $\mathbf{K}$ & 15.866 & 14.306 & 13.525 & 13.281 & 12.760 \\
\hline & $\mathbf{C a}$ & 14.049 & 13.134 & 12.656 & 12.368 & 11.931 \\
\hline & Mg & 14.703 & 13.656 & 13.173 & 12.910 & 12.556 \\
\hline & Zero & 11.880 & 10.577 & 9.970 & 9.723 & 9.499 \\
\hline \multirow{4}{*}{$1^{\text {st }}$ June } & $\mathbf{K}$ & 14.261 & 13.155 & 12.513 & 12.159 & 11.887 \\
\hline & $\mathrm{Ca}$ & 13.288 & 12.232 & 11.780 & 11.580 & 11.237 \\
\hline & Mg & 13.588 & 12.674 & 12.177 & 11.872 & 11.699 \\
\hline & Zero & 11.490 & 10.332 & 9.899 & 9.683 & 9.514 \\
\hline \multirow{4}{*}{$\begin{array}{c}1^{\text {st }} \\
\text { August }\end{array}$} & $\mathbf{K}$ & 11.890 & 11.133 & 10.630 & 10.252 & 10.010 \\
\hline & $\mathbf{C a}$ & 11.588 & 10.575 & 10.086 & 9.785 & 9.645 \\
\hline & Mg & 11.619 & 11.018 & 10.498 & 10.244 & 10.117 \\
\hline & Zero & 9.097 & 8.033 & 7.556 & 7.454 & 7.296 \\
\hline
\end{tabular}

Obtained values shown in Table 8 and Fig. 10 indicated that the highest cash advantage (23773.46 L.E.) was achieved from $2^{\text {nd }}$ planting date interacting with potassium spray after 120 days storage period, followed by magnesium (23398.25 L.E.) and calcium (22473.57 L.E.) which higher than all the monetary values resulting from stored yield of the first planting date $\left(1^{\text {st }}\right.$ April).

Table 8: Monetary value advantage (thousand pounds /fed) as affected by planting dates and macro nutrients foliar spray interaction over the average of both seasons

\begin{tabular}{|c|c|c|c|c|c|c|}
\hline \multirow{2}{*}{ Item } & & \multirow{2}{*}{ At harvest } & \multicolumn{4}{|c|}{ After take away the losses } \\
\hline & & & 30 days & 60 days & 90 days & 120 days \\
\hline \multirow{4}{*}{$1^{\text {st }}$ April } & $\mathbf{K}$ & 15866.0 & 14306.03 & 14877.75 & 17265.89 & 19140.08 \\
\hline & $\mathbf{C a}$ & 14049.0 & 13133.83 & 13922.04 & 16078.74 & 17895.93 \\
\hline & Mg & 14703.0 & 13656.46 & 14490.33 & 16783.54 & 18833.97 \\
\hline & Zero & 11880.0 & 10577.06 & 10967.10 & 12639.54 & 14248.19 \\
\hline \multirow{4}{*}{$1^{\text {st }}$ June } & $\mathbf{K}$ & 15687.1 & 17101.69 & 18769.10 & 21886.94 & 23773.46 \\
\hline & $\mathrm{Ca}$ & 14616.8 & 15901.90 & 17670.70 & 20843.23 & 22473.57 \\
\hline & Mg & 14946.8 & 16476.59 & 18266.20 & 21368.93 & 23398.25 \\
\hline & Zero & 12639.0 & 13431.52 & 14847.95 & 17430.16 & 19027.75 \\
\hline \multirow{4}{*}{$1^{\text {st }}$ August } & $\mathbf{K}$ & 17835.0 & 20040.08 & 21259.94 & 20504.83 & 19018.16 \\
\hline & $\mathrm{Ca}$ & 17382.0 & 19035.07 & 20171.51 & 19569.36 & 18324.95 \\
\hline & Mg & 17428.5 & 19831.95 & 20996.14 & 20487.50 & 19222.74 \\
\hline & Zero & 13645.5 & 14460.02 & 15112.95 & 14908.19 & 13862.54 \\
\hline
\end{tabular}

Results, also, cleared that the monetary value of yield on the first planting date decreases from the harvest time until 60 days of storage compared to other planting dates and then starts to increase by an amount to 108.8, 114.5, 114.2 and $106.4 \%$ (at 90 days) and 120.6, 127.4, 128.1 and $119.9 \%$ (at 120 days) more than its value at the time of harvest, i.e., Equivalent to $17265.9,16078.7,16783.5$ and 12639.5 L.E. at 90 days and 19140.0, 17895.9, 18833.97 and 14248.19 L.E. at 120 days using K, Ca, 
$\mathrm{Mg}$ and control, respectively (Tables $8 \& 9$ ). The proportions and monetary values differed according to the yield quantity at the time of harvest. Therefore, it is recommended that do not sold off the stored yield of April planting date before 90 and 120 days in order to avoid the loss resulting from the sale after storage periods of 30 or 60 days. Moreover, it is also clearly noted that monetary value for stored yield of June planting increases with the increase of the storage period up to 120 days reaches to the highest cash value than all treatments and other dates after 120 days storage period.

In contrast to the first planting date, the results show that the monetary value of the third planting period (August) increases gradually from the first storage period (30 days) to the maximum increase (21259.94 L.E.) at the end of the second storage period (60 days) under all spray treatments and then decreasing with increasing the storage period to 120 days without significant losses compared to no storage treatment.

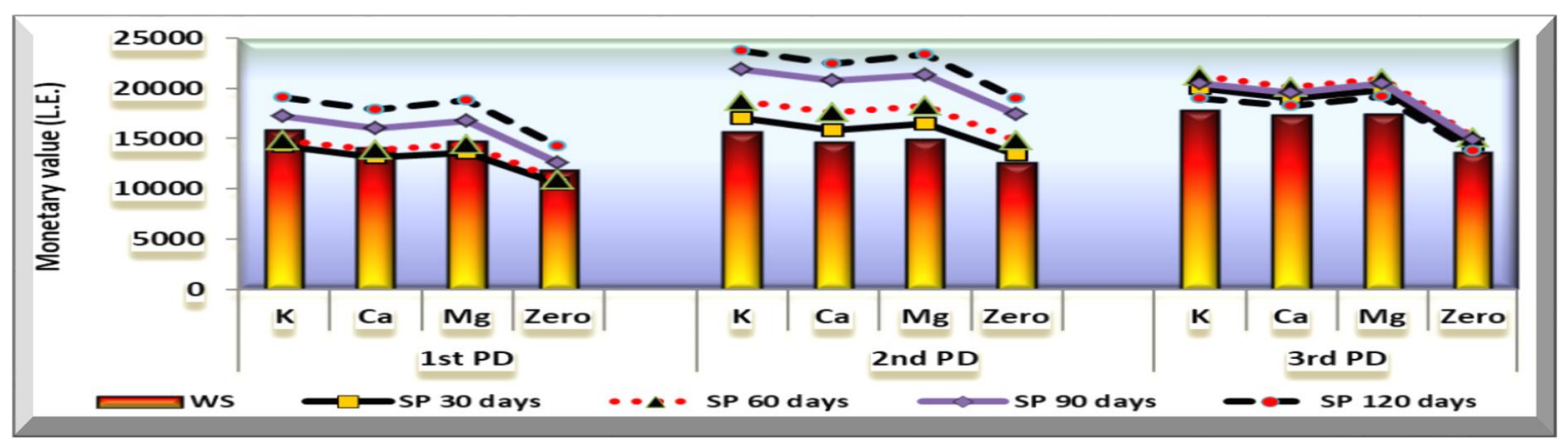

Fig. 10: Monetary value advantage (thousand pounds /fed) as affected by planting dates and nutrients foliar spray interaction over the average of both seasons

For farmers interested in getting maximum income, spraying sweet potato planted on $2^{\text {nd }}$ date with $\mathrm{K}$ and storage the harvested yield up to 120 days on-farm storage under naturally temperature would be the best treatment (gave 23.8 thousand pounds advantage as average of both seasons). While for farmers interested in getting high income and the highest yield at harvest time without storing the yield, the third planting date (August) using $\mathrm{K}, \mathrm{Mg}$ or Ca foliar spray would be recommended (gave 17.835, 17.429 and 17.382 thousand pounds, respectably). As for farmers interested in getting high income and the highest yield at harvest time without any nutrients foliar spray or storing the yield, $3^{\text {rd }}$ planting date also, would be recommended (gave 13.645 thousand pounds) more than $2^{\text {nd }}(12.639$ thousand pounds ) or $1^{\text {st }}$ planting date (11.880 thousand pounds ).

Again, the study showed that, sweet potato on-farm storage in is a viable and potentially highly profitable business in Egypt. We found that the longer the storage period (in case of $2^{\text {nd }}$ planting date), the higher the monetary value of the venture where, it increases with the increase of the storage period up to 120 days (Table 8 ). The highest values obtained are 23773.46 L.E. using potassium foliar sprays, followed by magnesium (23398.25 L.E.) and calcium (22473.57 L.E.) which higher than all the monetary values resulting from stored yield of the first planting date $\left(1^{\text {st }}\right.$ April). However, due to the present study, at the moment it is not possible to recommend storing sweet potatoes for more than 4 months with planting at June and 8 weeks with planting at August using nutrients foliar spray where, in the $3^{\text {rd }}$ planting date, the monetary value increases by increasing the storage period up to 60 days and then decreasing with increasing the storage period to 120 days without significant losses compared to no storage (the highest value obtained at 60 days under all treatments).

Storing sweet potatoes for 8 weeks (Both June and August planting dates) would still represent a viable business which is not recommended in April plantings where the stored yield do not sold off before 90 and 120 days (the highest monetary value under all nutrient treatments over the corresponding treatments at harvest time by storing April planting up to 120 days) in order to avoid the loss resulting from the sale after storage periods of 30 or 60 days. At current market prices (2017 season), sweet potatoes are sold at about 1, 1.1 and 1.5 L.E./kg (Table 2) for planting of April, June and August, respectively during the peak harvesting season. Even when taking into account the highest storage cost, farmers will realize an impressive marginal profit per season by storing tuber roots for 16 weeks. 
Table 9: Changes percentage of monetary value (MV) relative to both corresponding and the highest MV through storage periods at harvest time

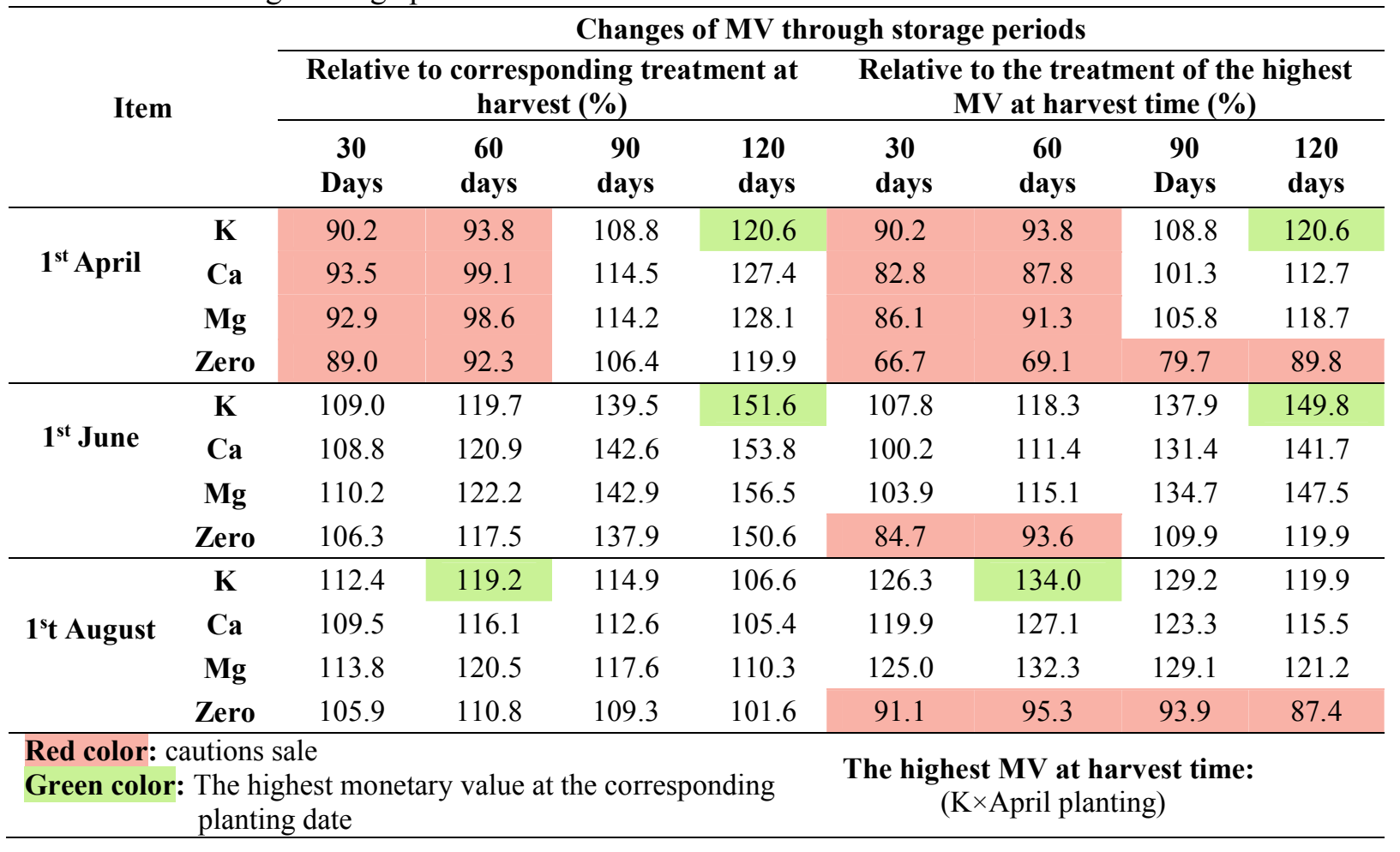

\section{Conclusion}

This study recommends planting sweet potato on the first of April or June dates and spraying with potassium, calcium and magnesium to obtain a high yield of tuberous roots, the return from it is determined by the market situation between supply and demand or planting in the third date (August) and spraying with the $(\mathrm{k}, \mathrm{Ca}$, and $\mathrm{Mg})$ to obtain relatively less production than the recommended planting date crop, but with a high cash return due to the lack of supply compared to previous dates and with a high storage capacity that enables the farmer control of marketing until reaching the appropriate return or creating new opportunities for export during this late period.

\section{References}

Allolli, T. B., S. I. Athani and S. J. Imamsaheb, 2011. Effect of different dates of planting on growth and yield performance of sweet potato (Ipomoea batatas L.) under Dharwad condition, Asian J. Hort., 6 (2): 303-305.

A.O.A.C., 1990. "Official Methods of Analysis of the Association of Official Analytical Chemists". $15^{\text {th }}+$ edition, published by Association of Official Analytical Chemists Arlington, Virginia U.S.A

Banerjee, H., A. Konar., A. V. V. Chakraborty and A.M. Puste, 2014. Impact of calcium nutrition on growth, yield and quality of potato (Solanum tuberosum L.). SAARC Journal of Agriculture, 12(1).

Blachinski, D., D. Shtienberg and A. Dinoor, 1996. Influence of foliar application of nitrogen and potassium on Alternaria diseases in potato, tomato and cotton. Phytoparasitica, 24(4): 281-292.

Brown, J.D and O. Lilliland, 1946. Rapid determination of potassium and sodium in plant material and soil extracts by flame photometry. Proc. Amer. Soc. Horticulture. Sci., 48: 341-346.

Byju, G and J. George, 2005. Potassium nutrition of sweet potato. Adv. Hort. Sci. 19(4): 221-239

Dash, S. N., Y. Pushpavathi and S. Behera, 2018. Effect of Irrigation and Mulching on Growth, Yield and Water Use Efficiency of Potato. Int. J. Curr. Microbiol. App. Sci., 7(2): 2582-2587

Dkhil, B. B., M. Denden and S. Aboud, 2011. Foliar Potassium Fertilization and its Effect on Growth, Yield and Quality of Potato Grown under Loam-sandy Soil and Semi-arid Conditions. Inter. J. Agri. Res., 6: 593-600. 
El-Denary, M.E.M., 1998. The performance of sweet potato (Ipomoea batatas L.) plants in response to cultural treatments. M.Sc. Thesis Fac. of Agric., Menoufiya Univ., Egypt.

El-Hadidi, E. M., R. A. El-Dissoky and Amal. A. H. AbdEl-hafez, 2017. Foliar calcium and magnesium application effect on potato crop grown in clay loam soils. J. Soil Sci. and Agric. Eng., Mansoura Univ., 8(1): 1- 8.

El-Sawy, M.B.I., 2011. Effect of soil fertilization and foliar spray of potassium on vegetative growth and yield and its components of sweet potato J. Plant Production, Mansoura Univ., 2 (3): 437 452 ,

El-Seifi, S. K., M. A. Hassan, Sawsan M. H. Serg., U. M. Saif El-Deen and M. A. Mohamed, 2014. Effect of calcium, potassium and some antioxidants on growth, yield and storability of sweet potato . Annals of Agric. Sci., Moshtohor, 52(1), 71-90.

El-Zohiri, S. S. M and M. E. A. Youssef, 2015. Response of Jerusalem artichoke to cut off irrigation before harvest and fertilization with Ca, Mg and B. J. Product.\& Dev., 20(1): 61-81.

George, M. S., L. GuoQuam and Z. WeiJum, 2002. Genotypic variation for potassium uptake and utilization efficiency in sweet potato (Ipomoea batatas, L.). Field Crops Res. 77(1): 7-15.

Gomez, K.A and A. A. Gomez, 1984. Statistical Procedures for Agricultural Research. $2^{\text {nd }}$ Ed., Jhon Wiley and Sons Inc., New York, pp: 95-109.

Gowda, P. H. R., H. B. Lingaiah., K. Seenappa and K. T. Shivashankara, 1990. Effect of potassium application on yield and yield components of sweet potato. J. Potass. Res., 6: 79-81.

Graham, D.R. (1983). Effects of nutrients stress on susceptibility of plants to disease with particular reference to the trace elements. Advances in Botanical Research, 10: 221-276.

Hamdi, W., L. Helali, R. Beji, K. Zhani, S. Ouertatani and A. Gharbi, 2015. Effect of levels calcium nitrate addition on potatoes fertilizer. Int. Res. J. of Eng. and Tech. (IRJET), 2(3): 2006-2013.

Harvat, R. J., R. F. Arrendale., G. G. Dull., G. Chapaman and J. J. Kays, 1991. Volatile constituents and sugars of three diverse cultivars of sweet potato (Ipomoea batatas). J. Food Sci., 56 (3):714.

Helal, N. A. S and S. A. AbdEl-hady, 2015. Calcium and potassium fertilization may enhance potato tuber yield and quality. Middle East J. of Agric. Res., 4(4): 991- 998.

Horneck, D. A and R. O. Miller, 1998. Determination of total nitrogen in plant tissue. In Handbook of reference methods for plant analysis; Karla, Y. P.; Ed.; Soil and Plant Science Council; CRC Press: Boca Raton, FL.

Hiller, L.K., 1995. Foliar fertilization Bumps potato yields in northwest. Rate and timing of application, plus host of other considerations, are critical in applying foliars to potatoes, Fluid Journal, 10: 2830.

Jackson, M. L., 1973. Soil Chemical Analysis. Printice-Hall of India. Privat Limited, New Delhi.

Mansour, F. Y. O and H. M. Abu El-Fotoh, 2018. Effect of planting date, irrigation level and foliar spraying with calcium and boron treatments on potato 1. plant growth, plant water relationship and plant chemical constituents. J. Product. \& Dev., 23(3): $755-788$.

Marschner, H., 2013. Mineral nutrition of higher plants ( $3^{\text {rd }}$ ed.) Academic Press, London, p. 285- 299.

Marschner, P., 2012. Mineral Nutrition of Higher Plants, 3rd ed.; Academic Press: London, UK,; pp. $178-189$.

Marschner, H., 1995. Mineral Nutrition of Higher Plants. (Academic Press Ltd.: London).

Martin, F.W., 1987. Planting dates and yields of four sweet potato clones in Puerto Rico. J. Agric. Univ. P. R. 71(4):379-384.

Mengel, K. and E.A. Kirkby, 2001. "Principles of Plant Nutrition". Springer Netherlands, $5^{\text {th }}$ Edn, 849pp., Annals of Botany, (2004 Apr), 93(4): 479-480.

Mishra, S., S. S. Mishra and U. P. Sinha, 1992. Studies on two tier cropping system of sweet potato in relation to fertility levels and growth regulators. J. Root Crops 18(1): 6-9.

Mishra, N., T. R. Mohanty., M. Ray and S. Das, 2019. Effect of Date of Planting on Growth, Yield and Economics of Sweet Potato (Ipomoea batatas L.) Varieties in Keonjhar District of Odisha, India. Int. J. Curr.Microbiol. App. Sci., 8(6): 2224-2229.

Nabukeera, C and D. Naziri, 2017. Technical report: Economic Viability of Ware Potato Storage in Ambient Stores in Eastern Uganda. The CGIAR Research Program on Roots, Tubers and Bananas (RTB). http://www.rtb.cgiar.org/endure. 
Nisha, K. M., R. S. Rathore and M. K. Meenai, 2020. Effect of Planting Dates and Plant Spacing on Growth and Yield Attributes of Sweet Potato [Ipomoea batatas (L.) Lam.] cv. CO-3-4. Int. J. Curr. Microbiol. App. Sci 9(4): 2602-2608

Ozgen, S., B. H. Karlsson and J. E. Palta, 2006. Response of potatoes (cv Russet burbank) to supplemental calcium applications under field conditions: tuber calcium, yield and incidence of internal brown spot. Amer. J. of Potato Res., 83:195-204.

Pregl, F., 1945. Quantitative Organic Micro Analysis. $4^{\text {th }}$ Edn., J. and A. Churchill Ltd., London.

Romheld, V. and E.A. Kirkby, 2010. Research on potassium in agriculture: Needs and prospects. Plant Soil, 335, 155-180.

Sangakkara, U. R., M. Frehner and J. Nosberger, 2000. Effect of soil moisture and potassium fertilizer on shoot water potential, photosynthesis and partitioning of carbon in mungbean and cowpea. J. Agron. Crop Sci., 185: 201-207.

Sandhu, A. S., S. P. Sharma, R. D. Bhutani and S. C. Khurana, 2014. Effects of planting date and fertilizer dose on plant growth attributesb and nutrient uptake of potato (Solanum tuberosum L.). International Journal of Agricultural Science, 4 (5): 196-202.

Talukder, M. A. H., M. B. Islam., S. M. A. H. M. Kamal., M. A. Mannaf and M. M. Uddin, 2009. Effects of magnesium on the performance of potato in the Tista Meander Floodplain soil. Bangladesh J. Agric. Res., 34(2): 255-261.

Walker, T.W and K. O. Fugulie, 2006. Prospects for Enhancing Value of Crops through Public-Sector Research: Lessons from Experiences with Roots and Tubers International Potato Center (CIP), Lima, Peru.

Watanabe, F. C and S. R. Olsen, 1965. Test of ascorbic acid method for determining phosphorus in water and $\mathrm{NaHCO}_{3}$ extracts from soils. Soil Sci. Soc. Am. Proc., 29: 677-678. 